Journal of Animal and Veterinary Advances 11 (12): 2159-2162, 2012

ISSN: $1680-5593$

(C) Medwell Journals, 2012

\title{
Comparison of Sanliurfa Pepper and Dry Tomato Paste in Enhancing Egg Yolk Color of Japanese Quails
}

\author{
${ }^{1} \mathrm{M}$. Avci, ${ }^{1} \mathrm{O}$. Kaplan and ${ }^{2} \mathrm{M}$. Yerturk \\ ${ }^{1}$ Department of Animal Nutrition, ${ }^{2}$ Department of Animal Science, \\ Faculty of Veterinary, Harran University, 63300 Sanliurfa, Turkey
}

\begin{abstract}
The objective of the present study was to investigate the effects of Sanliurfa Pepper (SP) and Tomato Paste (TP) on live weight change, feed intake, feed efficiency, egg qualities and egg yolk pigmentation in quails. One hundred and eighty Japanese quails, 15 weeks of age were randomly divided into three groups; one control and two experimental groups, comprising five replicates of 12 birds each. Two diets each contained SP or TP and a control diet. All products were added at a rate of $0.1 \%$. Visual assessment of yolk colour (Roche color fan) showed a stabilized yolk color of $9.80,13.33$ and 10.8 for the control, SP and TP treatments, respectively $(\mathrm{p}<0.001)$. Feed efficiency $(\mathrm{p}<0.05)$ increased significantly in the group given SP. Feed consumption decreased $(\mathrm{p}<0.05)$ depending on TP supplementation. However, SP and TP did not affect live weight change, egg production, egg weight, albumen weight, yolk weight, specific gravity, shape index, shell thickness and egg shell weight. In conclusion, an increase on yolk pigmentation in eggs produced by female quail fed diets supplemented with SP.
\end{abstract}

Key words: Quail, pepper, tomato, yolk colour, egg, Turkey

\section{INTRODUCTION}

The color of an egg's yolk is considered to be an important factor in determining the acceptability of a product for the consumer. In fact, consumers tend to associate golden yellow to orange yolk with good health. Consumer preferences for egg yolk pigmentation vary among countries and even between regions of the same country (Brufau, 1997). The color of egg yolk is a dietary response and a suitable degree of pigmentation and xanthophylls' content are of concern in table eggs as well as in eggs for manufacturers.

The yolk color depends not only on the levels of pigmenting substances namely xanthophylls present in the feed but also on the type and ratio of these compounds. Yolk pigmenters can be included in poultry feed via feed ingredients (i.e., corn gluten meal and alfalfa) and by addition of synthetic or natural pigments or a combination of both. For achieving optimal yolk coloration, hens' diets should be supplemented with yellow and red xanthophylls (Belyavin and Marangos, 1987). More recently however, consumers have become more concerned about the use of synthetic additives in foods and feeds and interest in natural alternatives has increased (Moeller et al., 2000; Johnson, 2002). Lycopene has created a demand for carotenoid-enriched products
(Agarwal and Rao, 2000; Porrini and Riso, 2000; Rao and Agarwal, 2000). Over recent years, there has been a marked trend toward the use of natural supplements in animal nutrition with marigold flower (Tagetes erecta) and paprika fruit (Capsicum annuum) as the main, natural sources of pigments. Paprika meal has high levels of capsanthin (4-8 $\mathrm{g} \mathrm{kg}^{-1}$ of total xanthophylls, $50-70 \%$ capsanthin) (Calafat, 2001).

In paprika, xanthophylls are usually esterified to fatty acids that is attached to fatty acids as the ester. In birds, esterified carotenoids have to be split (saponified) before they are absorbed (Hamilton et al., 1990). Dried tomato pomace, a byproduct of tomato processing is an excellent source of $\alpha$-tocopherol (Vitamin E) which is used as an antioxidant in broiler meat. Tomato pomace could be used as a source of $\alpha$-tocopherol in broiler diets to decrease lipid oxidation (fat deterioration) during heating and longterm frozen storage of dark meat and to prolong shelf life. Because tomato byproducts contain high levels of unsaturated fatty acids, the pomace must be defatted without losing Vitamin $\mathrm{E}$ to minimize its oxidation potential. Tomato pomace can contain up to $25 \%$ highlysine protein and 242 parts per million (ppm) of $\alpha$ tocopherol (Vitamin E). Tocopherols, especially the alpha form help prevent lipid oxidation (deterioration of fats). They preserve the quality of heated or stored meat by

Corresponding Author: M. Avci, Department of Animal Nutrition, Faculty of Veterinary, Harran University, 63300 Sanliurfa, Turkey 
reducing the end products of oxidation that cause discoloration, off odors and off flavors. Also, some byproducts of lipid oxidation may be hazardous to human health (Agarwal and Rao, 2000; Porrini and Riso, 2000; Rao and Agarwal, 2000).

The objective of the present study was to compare the pigmenting efficiency of Sanliurfa pepper and tomato on egg production, feed intake, feed efficiency, egg qualities and yolk color of laying Japanese quails.

\section{MATERIALS AND METHODS}

One hundred and eighty Japanese quails, 15 weeks of age were randomly divided into one control and two experimental groups, comprising five replicates of 12 birds each. The control diet was basal diet and other experimental diets were obtained by supplementing the basal diet with $1000 \mathrm{mg} \mathrm{kg}^{-1}$ Sanliurfa Pepper (SP) or $1000 \mathrm{mg} \mathrm{kg}^{-1}$ Tomato Paste (TP).

The birds were housed in $8 \times 7 \mathrm{~m}$ quail house equipped with 3 cages with wire mesh floor. Each caging unit also contained 5 sub cages $(50 \times 60 \times 30 \mathrm{~cm})$. Each cage compartment was equipped with a nipple drinker and a trough-type feeder. The animals were fed the research rations for 10 weeks. The amount of nutrients in the research rations were determined according to the methods described by AOAC (1996) while the level of Metabolizable Energy (ME) in the rations was determined according to the method described by TSE (1994) (Table 1).

Laying rate (number/bird/day), egg weight (g) and feed intake ( $\mathrm{g} /$ bird/day) were measured daily during the experimental period. Feed conversion ratio was calculated as the amount of feed required to produce $1 \mathrm{~kg}$ of egg.

Ten eggs from each of the three dietary groups laid up to 2 consecutive days during the 20 th and 25 th weeks of experimental feeding were utilized for quality testing in respect of egg shell weight, shell thickness, specific gravity, shape index, albumen weight, yolk weight and yolk color (Table 2 ).

The data were statistically analyzed by one-way ANOVA and the means were compared by Duncan's Multiple-range test (SPSS, 1996).

Table 1: Ingredients and chemical composition of the diets for Japanese quails

\begin{tabular}{|c|c|}
\hline Ingredients and chemical composition & Values \\
\hline \multicolumn{2}{|l|}{ Ingredients $\left(\mathrm{g} \mathrm{kg}^{-1}\right)$} \\
\hline Yellow com & 470.00 \\
\hline Wheat & 80.00 \\
\hline Soybean meal ( $44 \% \mathrm{CP})$ & 287.00 \\
\hline Fish meal $(60 \% \mathrm{CP})$ & 34.00 \\
\hline Vegetable oil & 50.00 \\
\hline Calcium carbonate & 68.00 \\
\hline Dicalcium phosphate & 5.00 \\
\hline Salt & 2.50 \\
\hline Vitamin premix ${ }^{a}$ & 2.50 \\
\hline Trace mineral premix ${ }^{b}$ & 1.00 \\
\hline \multicolumn{2}{|l|}{ Chemical composition $\left(\mathrm{g} \mathrm{kg}^{-1}\right)$} \\
\hline Dry matter & 894.90 \\
\hline Crude protein & 200.00 \\
\hline Crude fat & 74.70 \\
\hline Crude fibre & 30.00 \\
\hline Calcium & 24.90 \\
\hline Total phosphorus & 5.00 \\
\hline \multicolumn{2}{|l|}{ Calculated values } \\
\hline $\mathrm{ME}\left(\mathrm{MJ} \mathrm{kg}^{-1}\right)$ & 12.56 \\
\hline Lysine & 11.90 \\
\hline Methionine+Cystine & 7.50 \\
\hline \multicolumn{2}{|c|}{$\begin{array}{l}\text { aitamin mixture (Rovimix } 124 / \mathrm{V} \text { ) (per kg diet provided: Vitamin A, } \\
18750 \mathrm{IU} \text {; Vitamin D, } 3750 \mathrm{IU} \text {, Vitamin } \mathrm{E}, 18.75 \mathrm{IU} \text {; menadione, } 3.125 \\
\text { mg; Vitamin B1, } 1.25 \mathrm{mg} \text {; Vitamin B2, } 12.5 \mathrm{mg} \text {; niacin, } 87.5 \mathrm{mg} \text {; }- \\
\text { pantothenic acid, } 25 \mathrm{mg} \text {; Vitamin B12 } 5 \mathrm{mg} \text {; folic acid, } 2.5 \mathrm{mg} \text {; biotin, } \\
0.125 \mathrm{mg} \text {; }{ }^{\text {Trace }} \text { mineral (Remineral } \mathrm{CH} \text { ) (per kg diet provided: Mn, } \\
40 \mathrm{mg} \text {; Fe, } 12.5 \mathrm{mg} \text {; } \mathrm{Zn}, 25 \mathrm{mg} \text {; Cu, } 3.5 \mathrm{mg} \text {; Iodine, } 0.15 \mathrm{mg} \text {; Se, } \\
0.025 \mathrm{mg} \text {; Choline chloride, } 175 \mathrm{mg}\end{array}$} \\
\hline
\end{tabular}

Table 2: Lay ing performance and egg quality in quails

\begin{tabular}{|c|c|c|c|c|}
\hline Parametrs & Control & Group I & Group II & $\mathrm{p}$-value \\
\hline Initial live weight $(\mathrm{g})$ & $231.07 \pm 5.34$ & $230.80 \pm 7.210$ & $235.20 \pm 3.20$ & NS \\
\hline Final live weight $(\mathrm{g})$ & $214.50 \pm 9.54$ & $216.93 \pm 10.09$ & $214.93 \pm 5.29$ & NS \\
\hline Live weight change $8-20$ weeks ( $g /$ bird) & $16.57 \pm 8.03$ & $13.87 \pm 5.330$ & $20.27 \pm 2.31$ & NS \\
\hline Egg production, hen day $(\%)$ & $88.82 \pm 0.31$ & $88.92 \pm 2.030$ & $85.33 \pm 2.05$ & NS \\
\hline Egg weight $(\mathrm{g})$ & $11.69 \pm 0.31$ & $11.76 \pm 0.120$ & $11.42 \pm 0.27$ & NS \\
\hline Feed consumption $8-20$ weeks ( $\mathrm{g} / \mathrm{bird} /$ day $)$ & $30.70 \pm 0.52^{\mathrm{a}}$ & $29.56 \pm 0.340^{\mathrm{ab}}$ & $28.90 \pm 0.44^{b}$ & $*$ \\
\hline Feed efficiency & $2.96 \pm 0.02^{\mathrm{a}}$ & $2.83 \pm 0.010^{b}$ & $2.97 \pm 0.02^{\mathrm{a}}$ & $*$ \\
\hline \multicolumn{5}{|l|}{ Egg quality characteristics } \\
\hline Egg weight $(g)$ & $11.79 \pm 0.18$ & $11.81 \pm 0.190$ & $11.69 \pm 0.28$ & NS \\
\hline Shell weight $(\mathrm{g})$ & $1.19 \pm 0.01$ & $1.20 \pm 0.020$ & $1.14 \pm 0.03$ & NS \\
\hline Shell weight (Percentage of egg weight) & $10.08 \pm 0.08$ & $10.09 \pm 0.110$ & $9.80 \pm 0.12$ & NS \\
\hline Shell thickness (mm) & $0.20 \pm 0.05$ & $0.19 \pm 0.080$ & $0.21 \pm 0.07$ & NS \\
\hline Shape index & $78.59 \pm 0.77$ & $78.99 \pm 0.970$ & $78.51 \pm 0.99$ & NS \\
\hline Specific gravity $\left(\mathrm{g} \mathrm{mL}^{-1}\right)$ & $1.07 \pm 0.00$ & $1.07 \pm 0.000$ & $1.07 \pm 0.00$ & NS \\
\hline Albumen weight $(\mathrm{g})$ & $6.24 \pm 0.11$ & $6.19 \pm 0.200$ & $6.28 \pm 0.19$ & NS \\
\hline Albumen weight (Percentage of egg weight) & $52.97 \pm 0.54$ & $52.31 \pm 1.120$ & $53.70 \pm 0.66$ & NS \\
\hline Yolk weight $(\mathrm{g})$ & $4.36 \pm 0.09$ & $4.42 \pm 0.110$ & $4.26 \pm 0.10$ & NS \\
\hline Yolk weight (Percentage of egg weight) & $36.95 \pm 0.50$ & $37.51 \pm 1.080$ & $36.50 \pm 0.63$ & NS \\
\hline Yolk color & $9.80 \pm 0.17^{b}$ & $13.33 \pm 0.130^{\mathrm{a}}$ & $10.80 \pm 0.11^{\mathrm{c}}$ & ********; \\
\hline
\end{tabular}

${ }_{\mathrm{a}-c}$ Values bearing different alphabets in the same line indicates significant difference; NS $\mathrm{p}>0.05 ; * \mathrm{p}<0.001 ; * * * \mathrm{p}<0.001$ 


\section{RESULTS AND DISCUSSION}

The main purpose of this study was to compare the effect SP and TP on feed intake, feed efficiency, egg qualities and egg yolk pigmentation of quails. SP and TP addition to the ratio did not have any influence on live weight change, egg production and egg weight. This result was in agreement with the previous studies that have been reported where pigment supplementation had not been associated with changes in production (Hasin et al., 2006). Carrillo reported no change in egg production and egg weight when a marine alga was added to laying hen rations. Similar results had been observed by Halaj et al. (1999) and Garcia et al. (2002) when evaluating synthetic pigments. Similar results were found by McElroy et al. (1994) who administered capsaicin $\left(5 \pm 20 \mathrm{mg} \mathrm{kg}^{-1}\right)$ in the diet of broilers and found that it had no adverse effect on weight. Researchers found reduced feed consumption of birds feed TP compared with the control. The reduction in feed intake of the birds fed TP and SP in the present experiment suggests that palatability was a limiting factor for feed intake. Similary, Halle et al. (2009) observed a significant decrease in feed intake when adding chlorella vulgaris to laying hen diets. Significantly better FCR has also been obtained with SP supplementation. Similar results had been observed by Gurocak when evaluating synthetic pigments.

The results of internal and external quality characteristics obtained in this study except yolk color score did not vary significant $(\mathrm{p}>0.05)$. Previous experiment reported similar trend in the result for quality characteristics of eggs (Hasin et al., 2006). The differences in yolk color scores were highly significant between SP and other dietary groups $(\mathrm{p}<0.001)$. Yolk color score of the eggs laid by birds fed SP based diet was highest of all and differ significantly from TP and control group. The depletion of carotenoid levels in egg yolks observed when bird were fed the carotenoid-poor basal diet was relatively quick and this result is in agreement with results previously reported (Gouveia et al., 1996; Marusich and Bauernfeind, 1970; Fletcher and Halloran, 1981). This study confirms that the concentration of carotenoid in the egg reflected the concentration of carotenoids in the diets. Capsicum in the pepper is transferred from the feed to the egg yolk with high efficiency and this efficiency depends on carotenoid composition and content of the diet. This is in agreement with Suraj and Speake (1998) and data reported by $\mathrm{Na}$ et al. (2004) for laying hens. While it is generally accepted that the carotenoid profile of the diet determines the profile of the egg yolk (Surai, 2002) there is evidence of complicated discriminatory mechanisms which are responsible for preferential deposition of certain specific carotenoids in the egg yolk (Blount et al., 2002). The yolk color scores generally desired by consumers are around 11 on the Roche yolk egg color fan. Although, the color scores reached by the SP supplementation in the experiment were higher than that the behavior of the product indicates that its use in higher concentrations in the ration formulation should lead to higher color scores.

\section{CONCLUSION}

The results of this study shows that higher color scores of egg yolk can reflects addition of Sanliurfa pepper to ratio.

\section{REFERENCES}

AOAC, 1996. Official Methods of Analysis of the Association of Official Analytical Chemist. 16th Edn., AOAC, Arlington, VA.

Agarwal, S. and A.V. Rao, 2000. Tomato lycopene and its role in human health and chronic diseases. Can. Med. Assoc. J., 163: 739-744.

Belyavin, C.G. and A.G. Marangos, 1987. Natural Products for Egg Yolk Pigmentation. In: Recent Advances in Animal Nutrition, Haresign, W. and D.J.A. Cole (Eds.). Butterworths, London, pp: 47-68.

Blount, J.D., P.F. Surai, D.C. Houston and A.P. Moller, 2002. Patterns of yolk enrichment with dietary carotenoids in gulls: the roles of pigment acquisition and utilization. Func. Ecol., 16: 445-453.

Brufau, J., 1997. Yolk-the golden opportunity International table egg production supplement. Int. Poult. Prod., 5: $17-25$.

Calafat, F.A., 2001. Personal Communication. Industrial Tecnica Pecuaria S.A., Barcelona, Spain.

Fletcher, D.L. and R.H. Halloran, 1981. An evaluation of a commercially available marigold concentrate and paprika oleoresin on egg yolk pigmentation. Poult. Sci., 60: 1846-1854.

Garcia, E.A., A.A. Mendes, C.C. Pizzolante, H.C. Goncalves, R.P. Oliveira and M.A. Silva, 2002. Effect of cantaxantina levels on performance and egg quality of laying hens. Braz. J. Poult. Sci., 4: 1-4.

Gouveia, L., V. Veloso, A. Reis, H. Fernandes, J. Novais and J. Empis, 1996. Chlorella vulgaris used to colour egg yolk. J. Sci. Food Agric., 70: 167-172.

Halaj, M., P. Halaj, F. Valasek, F. Moravick and M. Melen, 1999. The effect of synthetic pigment addition to feed on the color of hen egg yolk. Czech J. Anim. Sci., 44: 187-192.

Halle, I., P. Janczyk, G. Freyer and W.B. Souffrant, 2009. Effect of microalgae Chlorella vulgaris on laying hen performance. Arch. Zootechnica, 12: 5-13. 
Hamilton, P., F. Tirado and F. Garcia-Hernandez, 1990. Deposition in egg yolks of the carotenoids from saponified and unsaponified oleoresin of red pepper (Capsicum annuum) fed to laying hens. Poult. Sci., 6: 462-470.

Hasin, B.M., A.J.M. Ferdaus, M.A. Islam, M.J. Uddin and M.S. Islam, 2006. Marigold and orange skin as egg yolk color promoting agents. Int. J. Poult. Sci., 5: 979-987.

Johnson, E.J., 2002. The role of carotenoids in human health. Nutr. Clin. Care, 5: 56-65.

Marusich, W.L. and J.C. Bauernfeind, 1970. Oxycarotenoid in poultry pigmentation. Yolk studies. Poult. Sci., 49: 1555-1566.

McElroy, A.P., J.G. Manning, L.A. Jaeger, M. Taub, J.D. Williams and B.M. Hargis, 1994. Effect of prologed administration of dietary capsaicin on broiler growth and Salmonella enteritidis susceptibility. Avian Dis., 38: 329-333.

Moeller, M.S., P.F. Jacques and J.B. Blumberg, 2000. The potential role of dietary xanthophylls in cataract and age-related macular degeneration. J. Am. Coll. Nutr., 19: $522 \mathrm{~S}-527 \mathrm{~S}$
Na, J.C., J.Y. Song, B.D. Lee, S.J. Lee, C.Y. Lee and G.H. An, 2004. Effects of polarity on absorption and accumulation of carotenoids by laying hens. Anim. Feed Sci. Technol., 117: 305-315.

Porrini, M. and P. Riso, 2000. Lymphocyte lycopene concentration and DNA protection from oxidative damage is increased in women after a short period of tomato consumption. J. Nutr., 130: 189-192.

Rao, A.V. and S. Agarwal, 2000. Role of antioxidant lycopene in cancer and heart disease. J. Am. Coll. Nutr., 19: 563-569.

SPSS, 1996. SPSS for Windows 9.3 Base Systems User's Guide. SPSS Inc., Chicago, IL USA.

Surai, P.F., 2002. Natural Antioxidants in Avian Nutrition and Reproduction. Nottingham University Press, Nottingham, ISBN: 9781897676950, Pages: 615.

Suraj, P.F. and B.K. Speake, 1998. Distribution of carotenoids from the yolk to the tissues of the chick embryo. J. Nutr. Biochem., 9: 645-651.

TSE, 1994. Animal feeds determintion of metabolizable energy (chemical method). Turkish Standards Institution, TS 9610, Ankara. 